\title{
Analisis Pengaruh Pengajaran Berbasis Teknologi Informasi Dan Sertifikasi Guru Terhadap Kompetensi Guru (Studi Kasus Di Sekolah Menengah Kejuruan Wilayah Tangerang Selatan)
}

\author{
Dian Rostikawati \\ Dosen Fakultas Ekonomi Universitas Pamulang \\ Email: drostikawati@gmail.com
}

\begin{abstract}
ABSTRAK
Tujuan dalam penelitian ini adalah: 1) Untuk mengetahui pengaruh pengajaran berbasis teknologi informasi terhadap kompetensi guru di Sekolah Menengah Kejuruan Wilayah Tangerang Selatan. 2) Untuk mengetahui pengaruh sertifikasi guru terhadap kompetensi guru di Sekolah Menengah Kejuruan Wilayah Tangerang Selatan. 3) Untuk mengetahui pengaruh pengajaran berbasis teknologi informasi dan sertifikasi guru secara bersama-sama terhadap kompetensi guru di Sekolah Menengah Kejuruan Wilayah Tangerang Selatan.

Penelitian ini bersifat deskriptif kuantitatif, populasi yang digunakan dalam penelitian ini sebanyak 352 guru Sekolah Menengah Kejuruan Wilayah Tangerang Selatan sudah sertifikasi. Teknik pengambilan sampel menggunakan rumus dari Slovin, sehingga sampel yang didapat sebanyak 187 orang.

Hasil penelitian ini menunjukkan bahwa: 1) Pengajaran berbasis teknologi informasi berpengaruh signifikan terhadap kompetensi guru, dengan nilai thitung 14.334 dan signifikansi 0.000. Karena thitung lebih besar ttabel $(14.334>1.973)$ dan signifikansi lebih kecil dari 5\% (0.000) maka Ha diterima dan H0 ditolak. Sedangkan nilai R Square 0.526, menunjukkan bahwa variabel (Y) dipengaruhi oleh variabel (X1) sebesar 52.6\% dan sisanya sebesar $47.4 \%$ dipengaruhi oleh faktor-faktor lain yang tidak diteliti. 2) Sertifikasi guru berpengaruh signifikan terhadap kompetensi guru, dengan nilai thitung 14.022 dan signifikansi 0.000 . Karena thitung lebih besar ttabel $(14.022>1.973)$ dan signifikansi lebih kecil dari 5\% (0.000) maka Ha diterima dan H0 ditolak, dapat dinyatakan bahwa sertifikasi guru (X2) berpengaruh signifikan terhadap kompetensi guru (Y). Sedangkan nilai $\mathrm{R}$ Square 0.515 hal ini menunjukkan bahwa variabel (Y) dipengaruhi oleh variabel (X2) sebesar $51.5 \%$ dan sisanya sebesar $48.5 \%$ dipengaruhi oleh faktorfaktor lain yang tidak diteliti. 3) Pengajaran berbasis teknologi informasi dan sertifikasi guru secara bersama-sama berpengaruh signifikan terhadap kompetensi guru, dengan nilai Fhitung 176.374 dan signifikansi 0.000. Jadi Fhitung > Ftabel, $(176.374>2.65)$ dan signifikansi lebih kecil dari $5 \%(0.000<0.05)$. Sedangkan nilai Adjusted $\mathrm{R}$ Square 0.653 hal ini menunjukkan bahwa variabel (Y) dipengaruhi oleh variabel (X1) dan variabel (X2) sebesar $65.3 \%$ dan sisanya sebesar $34.7 \%$ dipengaruhi oleh faktor-faktor lain yang tidak diteliti.
\end{abstract}

Kata Kunci: Pengajaran Berbasis Teknologi Informasi, Sertifikasi Guru, Kompetensi Guru 


\section{PENDAHULUAN}

\section{Latar Belakang}

praktik

Terjadinya

konvensional

pergeseran

pembelajaran menuju

pembelajaran berbasis teknologi informasi dan komunikasi dalam menggunakan multimedia pada pembelajaran juga menjadi penyebab rendahnya pembelajaran berbasis teknologi informasi di Sekolah Menengah Kejuruan Wilayah Tangerang Selatan. Selain itu kemampuan guru dalam mengoperasikan media berbasis TIK juga masih rendah, hal ini dikarenakan minimnya pengetahuan dan keahlian yang dimiliki guru Sekolah Menengah Kejuruan Wilayah Tangerang Selatan, sehingga kegiatan pembelajaran kurang bervariasi, tidak menarik, murid kurang aktif. Hal inilah yang membuat siswa di Sekolah Menengah Kejuruan Wilayah Tangerang Selatan tidak memperhatikan pelajaran dan menyebabkan pembelajaran berjalan tidak kondusif.

Guru merupakan sosok yang mengemban tanggung jawab untuk mewujudkan tujuan pendidikan nasional seperti yang telah dijelaskan dalam UU No. 20 Tahun 2003 tentang SISDIKNAS bahwa: Pendidikan Nasional berfungsi mengembangkan kemampuan dan membentuk watak serta peradaban bangsa yang bermartabat dalam rangka mencerdaskan kehidupan bangsa, bertujuan untuk berkembangnya potensi peserta didik agar menjadi manusia yang beriman, bertaqwa Kepada Tuhan Yang Maha Esa, berakhlak mulia, sehat, berilmu, cakap, kreatif, mandiri, dan menjadi warga negara yang demokratis serta bertanggung jawab.

Sertifikasi guru merupakan salah satu cara dalam dunia pendidikan untuk meningkatkan kualitas dan profesionalitas guru, sehingga ke depan semua guru harus memiliki sertifikat sebagai lisensi atau ijin mengajar. Dengan demikian, upaya pembentukan guru yang profesional di Indonesia segera menjadi kenyataan seperti yang diharapkan. Semakin meningkat kualitas dan profesionalitas guru, semakin baik pula kualitas negara tersebut. Itulah asumsi secara umum terhadap program pendidikan suatu negara. Pendidikan merupakan suatu upaya mencerdaskan kehidupan bangsa dan meningkatkan harkat dan martabat manusia melalui pendidikan diharapkan dapat tercapai peningkatan kehidupan manusia kearah yang lebih sempurna. Pelaksanaan program pendidikan didukung dengan kepemimpinan yang demokratis dan profesional, guru yang profesional dan memiliki kompetensi dalam bidangnya masing-masing, serta tenaga administrasi professional dalam pengelolaan administrasi pendidikan.

Dalam hal ini, guru tidak semata-mata sebagai pengajar yang melakukan transfer ilmu pengetahuan kepada siswanya, tetapi guru juga sebagai pendidik yang melakukan transfer nilainilai sekaligus sebagai 
pembimbing yang memberikan pengarahan dan menuntun semua siswa dalam belajar. Guru adalah modal utama di dalam bidang pendidikan. Guru sebagai modal utama dalam bidang pendidikan mempunyai pikiran, perasaan, status, keinginan dan latar belakang yang heterogen. Oleh sebab itu, bidang pendidikan harus bisa mendorong setiap guru agar tetap memiliki kinerja yang baik dalam mengerjakan tugastugasnya yaitu sebagai pendidik dengan memberikan sesuatu yang dapat memberi rasa puas bagi guru itu sendiri. Fathoni (2006:175), menyatakan bahwa untuk melihat kepuasan kerja pegawai dapat dilihat dari kedisiplinan, turnover kecil dan juga moral kerja. Hasibuan (2007:202) juga menyatakan bahwa kepuasan kerja pegawai adalah sikap emosional yang menyenangkan dan mencintai pekerjaannya sendiri. Sikap ini dicerminkan oleh moral kerja pegawai, kedisiplinan, dan prestasi kerja pegawai.

Berdasarkan permasalahan yang dihadapi oleh guru-guru yang ada di Sekolah Menengah Kejuruan Wilayah Tangerang Selatan mengenai pengajaran berbasis teknologi informasi, sertifikasi guru dan kompetensi yang dimiliki guru Sekolah Menengah Kejuruan Wilayah Tangerang. Maka penulis tertarik untuk melakukan penelitian dengan judul yang ingin diteliti adalah: "Analisis Pengaruh Pengajaran Berbasis Teknologi Informasi dan Sertifikasi Guru Terhadap Kompetensi Guru
(Studi Kasus di Sekolah Menengah Kejuruan Wilayah Tangerang Selatan)".

2. Identifikasi Masalah

Beberapa permasalahan yang ada di Sekolah Menengah Kejuruan Wilayah Tangerang Selatan mengenai pengajaran berbasis teknologi informasi dan sertifikasi guru terhadap kompetensi guru dapat diidentifikasikan sebagai berikut:

1. Kurangnya perhatian dari lembaga terkait (belum mengadakan sosialisasi dan pelatihan tentang pemanfaatan teknologi informasi untuk mendukung proses pembelajaran), sehingga sarana prasarana yang sudah tersedia di Sekolah Menengah Kejuruan Wilayah Tangerang Selatan belum dapat di manfaatkan dengan baik.

2. Rendahnya minat guru Sekolah Menengah Kejuruan Wilayah Tangerang Selatan dalam pemanfaatan dan penggunaan media berbasis teknologi dan komunikasi dalam proses pembelajaran.

3. Masih kurangnya pemanfaatan teknologi komputer sebagai media pembelajaran dengan perpaduan antara pendidikan dan kreativitas dalam belajar.

4. Terjadinya pergeseran praktik pembelajaran konvensional menuju pembelajaran berbasis teknologi informasi dan komunikasi dalam menggunakan multimedia pada pembelajaran.

5. Kurangnya perhatian guru Sekolah Menengah Kejuruan Wilayah Tangerang Selatan 
terhadap mutu pendidikan yang ada.

6. Rendahnya kemampuan guru dalam mengolah materi pembelajaran berbasis media teknologi informasi dan komunikasi.

7. Rendahnya produktivitas kerja guru sertifikasi.

8. Kurangnya upaya guru Sekolah Menengah Kejuruan Wilayah Tangerang Selatan dalam menciptakan sumber daya manusia berkualitas.

9. Kegiatan pembelajaran kurang bervariasi, tidak menarik dan masih cenderung konvensional, sehingga pada waktu kegiatan belajar mengajar berlangsung siswa tidak memperhatikan pelajaran dan membuat gaduh yang menyebabkan pembelajaran berjalan tidak kondusif.

10. Guru Sekolah Menengah Kejuruan Wilayah Tangerang Selatan belum memiliki kompetensi yang cukup untuk mengajar, yang dapat dilihat dari kemampuan dalam melaksanakan tugas-tugas dan tanggungjawabnya.

\section{Perumusan Masalah}

Bertolak dari identifikasi dan pembatasan masalah di atas, maka secara operasional permasalahan yang diteliti dapat dirumuskan sebagai berikut:

1. Apakah pengajaran berbasis teknologi informasi berpengaruh terhadap kompetensi guru di Sekolah Menengah Kejuruan Wilayah Tangerang Selatan?

2. Apakah sertifikasi guru berpengaruh terhadap kompetensi guru di Sekolah Menengah Kejuruan Wilayah Tangerang Selatan?

3. Apakah pengajaran berbasis teknologi informasi dan sertifikasi guru secara bersamasama berpengaruh terhadap kompetensi guru di Sekolah Menengah Kejuruan Wilayah Tangerang Selatan?

\section{TINJAUAN PUSTAKA}

\section{Pengajaran Berbasis Teknologi Informasi}

\section{Pengajaran}

Makna pembelajaran dalam Kamus Besar Bahasa Indonesia, adalah proses, cara perbuatan menjadikan orang atau makhluk hidup belajar. Lebih lanjut, Sanjaya (2008:51) mengemukakan bahwa pembelajaran merupakan kegiatan yang bertujuan membelajarkan siswa. Undang-Undang Republik Indonesia Nomor 20 Tahun 2003 tentang Sistem Pendidikan Nasional, mengemukakan bahwa pembelajaran adalah proses interaksi peserta didik dengan pendidik dan sumber belajar pada suatu lingkungan belajar.

Setiap guru penting untuk memahami sistem pembelajaran, karena dengan pemahaman sistem ini, setiap guru akan memahami tentang tujuan pembelajaran atau hasil yang diharapkan, proses kegiatan pembelajaran yang dilakukan, pemanfaatan setiap komponen dalam proses kegiatan untuk mencapai tujuan yang ingin dicapai dan bagaimana mengetahui keberhasilan pencapaian tersebut. Tujuan pembelajaran adalah kompetensi 
atau keterampilan yang diharapkan dapat dimiliki oleh siswa setelah mereka melakukan proses pembelajaran tertentu, (Sanjaya, 2008:86).

Lebih lanjut, Sanjaya (2008:88) mengemukakan bahwa rumusan tujuan pembelajaran harus mengandung unsur ABCD, yaitu Audience (siapa yang harus memiliki kemampuan), Behaviour (perilaku yang bagaimana yang diharapkan dapat dimiliki), Condition (dalam kondisi dan situasi yang bagaimana subjek dapat menunjukkan kemampuan sebagai hasil belajar yang telah diperolehnya), dan Degree (kualitas atau kuantitas tingkah laku yang diharapkan dicapai sebagai batas minimal).

\section{Sertifikasi Guru}

Dalam Undang-Undang

Nomor 14 Tahun 2005 dikemukakan bahwa sertifikasi adalah proses pemberian sertifikat pendidik untuk guru dan dosen. Sedangkan sertifikat pendidik adalah bukti formal sebagai pengakuan yang diberikan kepada guru dan dosen sebagai tenaga profesional. Berdasarkan pengertian tersebut, sertifikasi dapat diartikan sebagai pemberian pengakuan bahwa seseorang telah memiliki kompetensi untuk melaksanakan pelayanan pendidikan pada satuan pendidikan tertentu, setelah lulus uji kompetensi yang diselenggarakan oleh lembaga sertifikasi. Dengan kata lain, sertifikasi adalah proses uji kompetensi yang dirancang untuk mengungkapkan penguasaan kompetensi seseorang sebagai landasan pemberian sertifikat pendidik, (Mulyasa, 2008:34).

Definisi sertifikasi adalah proses pemberian sertifikat pendidik untuk guru dan dosen. Sertifikasi pendidik adalah bukti formal sebagai pengakuan yang diberikan kepada guru dan dosen sebagai tenaga profesional (UU RI No 14 Tahun 2005 dalam Depdiknas, 2004). Berdasarkan pengertian tersebut, sertifikasi dapat diartikan sebagai proses pemberian pengakuan bahwa seseorang telah memiliki kompetensi untuk melaksanakan pelayanan pendidikan pada satuan pendidikan tertentu, setelah lulus uji kompetensi yang diselenggarakan oleh lembaga sertifikasi. Dengan kata lain, sertifikasi guru adalah proses uji kompetensi yang dirancang untuk mengungkapkan penguasaan kompetensi seseorang sebagai landasan pemberian sertifikat pendidik.

Sertifikasi merupakan pemenuhan kebutuhan untuk meningkatkan kompetensi profesional. Oleh karena itu, sertifikasi dipandang sebagai bagian esensial dalam upaya memperoleh sertifikat kompetensi sesuai standar yang ditetapkan. Sertifikasi merupakan proses uji kompetensi bagi calon atau guru yang ingin memperoleh pengakuan atau meningkatkan kompetensi sesuai profesi yang dipilih. Representasi pemenuhan standar kompetensi yang telah ditetapkan dalam sertifikasi kompetensi adalah sertifikat kompetensi pendidik. Sertifikat ini sebagai bukti pengakuan atas 
kompetensi guru atau calon guru yang memenuhi standar untuk melakukan pekerjaan profesi guru pada jenis dan jenjang pendidikan tertentu.

\section{Kompetensi Guru}

Konsep kompetensi

bukanlah hal baru di dalam psikologi organisasi industri Amerika yang sudah memiliki gerakan kompetensi sejak akhir tahun 1960 dan awal tahun 1970, (Rivai dan Sagala, 2009:296). Para pakar manajemen SDM dan perilaku organisasi pada umumnya memberikan batasan berbeda mengenai konsep kompetensi, tetapi secara tersirat batasan yang terkandung dalam pengertian para pakar tersebut relatif memiliki kesamaan bahwa kompetensi adalah karakteristik utama dari individu untuk menghasilkan kinerja optimal dalam melakukan pekerjaan yang mencakup motif, sifat, konsep diri, pengetahuan, dan keahlian.

\section{METODE PENELITIAN}

Penelitian ini bersifat deskriptif kuantitatif, populasi yang digunakan dalam penelitian ini sebanyak 352 guru Sekolah Menengah Kejuruan Wilayah Tangerang Selatan sudah sertifikasi. Teknik pengambilan sampel menggunakan rumus dari Slovin, sehingga sampel yang didapat sebanyak 187 orang.

\section{HASIL DAN PEMBAHASAN}

\section{Pengaruh Pengajaran Berbasis}

Teknologi Informasi $\left(\mathrm{X}_{1}\right)$ terhadap Kompetensi Guru (Y)

Terdapat

pengajaran berbasis

informasi pengaruh

teknologi terhadap kompetensi guru (Y) dengan bukti nilai $t_{\text {hitung }}$ yang didapat sebesar 14.334 dan signifikansi sebesar 0.000. Karena $t_{\text {hitung }}$ lebih besar $\mathrm{t}_{\text {tabel }}(14.334>1.973)$ dan signifikansi lebih kecil dari 5\% (0.000) maka $\mathrm{H}_{\mathrm{a}}$ diterima dan $\mathrm{H}_{0}$ ditolak. Sedangkan nilai R Square yang diperoleh sebesar 0.526, hal ini menunjukkan bahwa variabel Y (kompetensi guru) dipengaruhi oleh variabel $\mathrm{X}_{1}$ (pengajaran berbasis teknologi informasi) sebesar $52.6 \%$ dan sisanya sebesar $47.4 \%$ dipengaruhi oleh faktorfaktor lain yang tidak diteliti. Hal ini sesuai dengan penelitian Rohmad (2009) yang menyatakan bahwa kompetensi guru dalam pembelajaran berbasis teknologi informasi di sekolah banyak dipengaruhi faktor kapasitas dan skill individu serta ketersediaan infrastruktur sarana dan prasarana di sekolah. Jika dua faktor itu terpenuhi maka ia menjadi pendukung kompetensi guru dalam pembelajaran berbasis teknologi informasi di sekolah.

Dan jika kedua faktor itu kurang terpenuhi atau belum tersedia, maka ia menjadi sebaliknya sebagai penghambat kompetensinya dalam melaksanakan pembelajaran berbasis teknologi informasi di sekolah.

2. Pengaruh Sertifikasi Guru $\left(\mathbf{X}_{2}\right)$ terhadap Kompetensi Guru (Y)

Terdapat pengaruh sertifikasi guru $\left(\mathrm{X}_{2}\right)$ terhadap kompetensi guru (Y) dengan bukti nilai $t_{\text {hitung }}$ yang didapat sebesar 14.022 dan signifikansi sebesar 0.000. Karena $t_{\text {hitung }}$ lebih besar $\mathrm{t}_{\text {tabel }}(14.022>1.973)$ dan 
signifikansi lebih kecil dari 5\% (0.000) maka $\mathrm{H}_{\mathrm{a}}$ diterima dan $\mathrm{H}_{0}$ ditolak. Sedangkan nilai R Square yang diperoleh sebesar 0.515 , hal ini menunjukkan bahwa variabel $\mathrm{Y}$ (kompetensi guru) dipengaruhi oleh variabel $\mathrm{X}_{2}$ (sertifikasi guru) sebesar $51.5 \%$ dan sisanya sebesar $48.5 \%$ dipengaruhi oleh faktorfaktor lain yang tidak diteliti. Hal ini sesuai dengan penelitian Murdadi dan Sulistari (2015) yang menyatakan bahwa program sertifikasi dilakukan supaya guru memiliki penguasaan kompetensi sebagaimana dipersyaratkan UU Guru dan Dosen.

Tujuan sertifikasi untuk meningkatkan kualitas pendidikan, menentukan kelayakan guru sebagai agen pembelajaran, meningkatkan martabat guru, dan meningkatkan profesionalisme seorang guru.

3. Pengaruh Pengajaran Berbasis Teknologi Informasi $\left(X_{1}\right)$ dan Sertifikasi Guru $\left(\mathbf{X}_{2}\right)$ terhadap Kompetensi Guru (Y)

\section{Terdapat pengaruh} sertifikasi guru pengajaran berbasis teknologi informasi $\left(\mathrm{X}_{1}\right)$ dan sertifikasi guru $\left(\mathrm{X}_{2}\right)$ terhadap kompetensi guru (Y) dengan bukti nilai $F_{\text {hitung }}$ sebesar 176.374 dan signifikansi sebesar 0.000. Jadi $\mathrm{F}_{\text {hitung }}>\mathrm{F}_{\text {tabel }},(176.374>2.65)$ dan signifikansi lebih kecil dari $5 \%(0.000<0.05)$. Sedangkan nilai Adjusted $\mathrm{R}$ Square yang diperoleh sebesar 0.653 yang menunjukkan bahwa variabel $\mathrm{Y}$ (kompetensi guru) dipengaruhi oleh variabel $\mathrm{X}_{1}$ (pengajaran berbasis teknologi informasi) dan variabel $\mathrm{X}_{2}$ (sertifikasi guru) sebesar $65.3 \%$ dan sisanya sebesar
$34.7 \%$ dipengaruhi oleh faktorfaktor lain yang tidak diteliti. Hal ini sesuai dengan penelitian Niarsa (2013) yang menyatakan bahwa dalam hal penggunaan media pembelajaran, kompetensi yang dimiliki guru adalah penggunaan media pembelajaran berbasis TIK secara tidak langsung dapat menambah pengetahuan siswa tentang perkembangan teknologi, sehingga guru harus lebih giat lagi dalam meningkatkan kompetensinya dalam penggunaan media pembelajaran yang digunakan sebagai media pendukung dalam proses pembelajaran dengan mengikuti kursus komputer atau pelatihan yang diadakan oleh pihak terkait, agar media pembelajaran yang digunakan dapat dimanfaatkan sesuai dengan materi ajar, kebutuhan siswa, kondisi lingkungan dan sesuai dengan tujuan yang ingin dicapai.

\section{PENUTUP}

\section{A. Kesimpulan}

Setelah diuraikan tentang "Analisis Pengaruh Pengajaran Berbasis Teknologi Informasi dan Sertifikasi Guru Terhadap Kompetensi Guru (Studi Kasus di Sekolah Menengah Kejuruan Wilayah Tangerang Selatan)", maka dari hasil analisis dan pembahasan pada bagian terdahulu, penulis akan mengambil suatu kesimpulan dari hasil penelitian ini sebagai berikut:

1. Pengajaran berbasis teknologi informasi berpengaruh signifikan terhadap kompetensi 
guru, dengan nilai $t_{\text {hitung }}$ sebesar 14.334 dan signifikansi sebesar 0.000. Karena $t_{\text {hitung }}$ lebih besar $\mathrm{t}_{\text {tabel }}(14.334>1.973)$ dan signifikansi lebih kecil dari 5\% (0.000) maka $\mathrm{H}_{\mathrm{a}}$ diterima dan $\mathrm{H}_{0}$ ditolak. Sedangkan nilai $\mathrm{R}$ Square sebesar 0.526 yang menunjukkan bahwa variabel Y (kompetensi guru) dipengaruhi oleh variabel $\mathrm{X}_{1}$ (pengajaran berbasis teknologi informasi) sebesar $52.6 \%$ dan sisanya sebesar $\quad 47.4 \%$ dipengaruhi oleh faktor-faktor lain yang tidak diteliti.

2. Sertifikasi guru berpengaruh signifikan terhadap kompetensi guru, dengan nilai $t_{\text {hitung }}$ sebesar 14.022 dan signifikansi sebesar 0.000. Karena $t_{\text {hitung }}$ lebih besar $t_{\text {tabel }}(14.022>1.973)$ dan signifikansi lebih kecil dari 5\% (0.000) maka $\mathrm{H}_{\mathrm{a}}$ diterima dan $\mathrm{H}_{0}$ ditolak, dapat dinyatakan bahwa sertifikasi guru $\left(\mathrm{X}_{2}\right)$ berpengaruh signifikan terhadap kompetensi guru (Y). Sedangkan nilai $\mathrm{R}$ Square sebesar $\quad 0.515 \quad$ yang menunjukkan bahwa variabel Y (kompetensi guru) dipengaruhi oleh variabel $\mathrm{X}_{2}$ (sertifikasi guru) sebesar $51.5 \%$ dan sisanya sebesar $48.5 \%$ dipengaruhi oleh faktorfaktor lain yang tidak diteliti.

3. Pengajaran berbasis teknologi informasi dan sertifikasi guru secara bersama-sama berpengaruh signifikan terhadap kompetensi guru, dengan nilai $F_{\text {hitung }}$ sebesar 176.374 dan signifikansi sebesar 0.000. Jadi $\mathrm{F}_{\text {hitung }}>$ $\mathrm{F}_{\text {tabel}},(176.374>2.65)$ dan signifikansi lebih kecil dari 5\% $(0.000<0.05)$. Sedangkan nilai Adjusted R Square sebesar 0.653 yang menunjukkan bahwa variabel Y (kompetensi guru) dipengaruhi oleh variabel $\mathrm{X}_{1}$ (pengajaran berbasis teknologi informasi) dan variabel $\mathrm{X}_{2}$ (sertifikasi guru) sebesar $65.3 \%$ dan sisanya sebesar $34.7 \%$ dipengaruhi oleh faktor-faktor lain yang tidak diteliti.

\section{B. Saran}

Adapun keterbatasan dan saran yang dapat kami sampaikan baik bagi instansi maupun bagi penelitian selanjutnya adalah sebagai berikut:

1. Berdasarkan pada pembahasan hal 109 disarankan agar guru mengembangkan media pembelajaran berbasis teknologi informasi, agar memudahkan guru dalam proses pengajaran dan meminimaaliskan waktu pengajaran. Selain itu guru juga dapat mencari sumber informasi yang akurat dalam meningkatkan kualitas mengajar dengan cara meningkatkan pemahaman guru dalam penggunaan media berbasis teknologi informasi, agar pengajaran berbasis teknologi informasi dapat dijadikan sebagai sumber informasi bagi guru dan diharapkan penggunaan media pembelajaran ini dapat mempermudah guru Sekolah Menengah Kejuruan Wilayah Tangerang Selatan dalam proses pengajaran. 
2. Berdasarkan pada pembahasan hal 109 disarankan agar kepala sekolah menentukan kelayakan guru sebagi agen pembelajaran. Selain itu juga kepala sekolah meningkatkan martabat guru agar guru merasa senang dalam bekerja dan kinerja guru dapat meningkat.

3. Berdasarkan pada pembahasan hal 114 disarankan agar guru Sekolah Menengah Kejuruan Wilayah Tangerang Selatan memiliki sikap yang baik dan sopan terhadap semua orang dan guru memiliki kemampuan yang baik dalam membantu menyelesaikan pekerjaan yang sulit, agar prestasi kerja guru meningkat. Selain itu juga guru di Sekolah Menengah Kejuruan Wilayah Tangerang Selatan menunjukkan reaksi yang positif pada saat mendapatkan pekerjaan yang sulit dan memiliki keyakinan bahwa hasilnya akan optimal.

4. Berdasarkan pada pembahasan hal 120 bahwa nilai $t$ hitung yang didapat untuk variabel $\mathrm{X}_{2}$ lebih kecil dari pada nilai $\mathrm{t}$ hitung untuk variabel $\mathrm{X}_{1}$, sehingga disarankan agar guru tetap melakukan pengembangan diri dan meningkatkan kualitas meskipun telah memiliki sertifikat pendidik, sehingga guru dapat meningkatkan kompetensi dan kinerjanya.

\section{DAFTAR PUSTAKA}

Asmani, J.M. 2011. Buku Panduan Internalisasi Pendidikan Karakter di Sekolah. Jogjakarta: DIVA Press.
Depdiknas. 2004. Materi Pelatihan Terintergrasi Bahasa dan Sastra Indonesia. Jakarta: Dirjen Pendidikan Dasar dan Menengah Depdiknas.

Fajar, Arnie. 2006. Peranan Sertifikasi Guru Dalam Meningkatkan Profesionalisme Guru. Bandung: Disdik Jawa Barat.

Fathoni, Abdurrahmat. 2006. Manajemen Sumber Daya Manusia. Bandung: Rineka Cipta.

Hamalik, Oemar. 2010. Kurikulum dan Pembelajaran. Jakarta: Bumi Aksara.

Hasibuan, Malayu S.P. 2007. Manajemen Sumber Daya Manusia. Jakarta: PT. Bumi Aksara.

Palan, R. 2003. Competence Management-A Practicionser's Guide (Competency Management,) Penterjemah: Octa Melia Jalal. Jakarta: PPM. Riduwan. 2006. Metode dan Teknik Menyusun Tesis, Cetakan 4. Bandung: Alfabeta.

Rivai, Veithzal., dan Sagala, Jauvani. 2009. Manajemen Sumber Daya Manusia untuk Perusahaan Dari Teori ke Praktik. Jakarta: PT Rajagrafindo Persada.

Sanjaya, Wina. 2008. Strategi Pembelajaran Berorientasi Standar Proses. Pendidikan. Jakarta: Kencana.

Sekaran, Uma. 2006. Research Methods for Business, Edisi 4, Buku 1. Jakarta: Salemba Empat.

Sugiyono. 2008. Metode Penelitian Kunatitatif Kualitatif dan R\&D. Bandung: Alfabeta. 
